\title{
Profile of suvorexant in the management of insomnia
}

\author{
This article was published in the following Dove Press journal: \\ Drug Design, Development and Therapy \\ II November 2015 \\ Number of times this article has been viewed
}

\author{
Eliza L Sutton \\ Department of Medicine, University \\ of Washington, Seattle, WA, USA
}

Correspondence: Eliza L Sutton

Department of Medicine, University of Washington Box 354765, 1959 NE Pacific Street, Seattle, WA 98195, USA

Email esutton@u.washington.edu
Abstract: Suvorexant, approved in late 2014 in the United States and Japan for the treatment of insomnia characterized by difficulty achieving and/or maintaining sleep, is a dual orexin receptor antagonist and the first drug in its class to reach the market. Its development followed from the 1998 discovery of orexins (also called hypocretins), excitatory neuropeptides originating from neurons in the hypothalamus involved in regulation of sleep and wake, feeding behavior and energy regulation, motor activity, and reward-seeking behavior. Suvorexant objectively improves sleep, shortening the time to achieve persistent sleep and reducing wake after sleep onset, although at approved doses $(\leq 20 \mathrm{mg})$ the benefit was subjectively assessed as modest. Its half-life of 12 hours is relatively long for a modern hypnotic; however, at approved doses ( $\leq 20 \mathrm{mg}$ ) next-day sedation and driving impairment were much less apparent than at higher doses. Suvorexant is metabolized by the hepatic CYP3A system and should be avoided in combination with strong CYP3A inhibitors. Drug levels are higher in women and obese people; hence, dosing should be conservative in obese women. Administration with food delays drug absorption and is not advised. No dose adjustment is needed for advanced age, renal impairment, or mild-to-moderate hepatic impairment. Suvorexant in contraindicated in narcolepsy and has not been studied in children. In alignment with the changes begun in 2013 in the labeling of other hypnotics, the United States Food and Drug Administration advises that the lowest dose effective to treat symptoms be used and that patients be advised of the possibility of next-day impairment in function, including driving. Infrequent but notable side effects included abnormal dreams, sleep paralysis, and suicidal ideation that were dose-related and reported to be mild. Given its mechanism of action, cataplexy and rapid eye movement (REM) sleep behavior disorder could potentially occur in some patients taking this medication.

Keywords: insomnia, hypnotic, dual orexin receptor antagonist, orexin, hypocretin

\section{Introduction}

Suvorexant, approved for marketing in the United States by the Food and Drug Administration (FDA) in August $2014^{1}$ and in Japan by the Pharmaceuticals and Medical Devices Agency in November 2014, ${ }^{2}$ is first in many categories:

- first-ever approved pharmaceutical that acts at orexin receptors;

- first sleep medication in a new class since the melatonin receptor agonist ramelteon in 2005;

- first sleep medication approved since the FDA began changing labeling, starting with zolpidem in 2013, to reflect heightened caution about the next-day effects of hypnotics. $^{3}$

Suvorexant enters a market hungry for sleep medications. Insomnia, defined in the International Classification of Sleep Disorders ${ }^{4}$ as: 
Persistent difficulty with sleep initiation, duration, consolidation, or quality that occurs despite adequate opportunity and circumstances for sleep, and results in some form of daytime impairment

is a very common and bothersome problem. In a 2014 survey in the United States asking about adults' experience over the prior week, $45 \%$ of respondents reported having had difficulty falling asleep at least one night and 16\% reported difficulty $\geq 5$ nights; $52 \%$ reported having had difficulty staying asleep at least one night and 23\% reported difficulty $\geq 5$ nights; and $17 \%$ of adults reported having taken a prescription or over-the-counter medication for sleep at least once, with $10 \%$ reporting use for $\geq 5$ nights. ${ }^{5}$ Insomnia of moderate-to-high severity is associated with high health care costs and lost productivity, with productivity particularly affected in those with insomnia who have chronic psychiatric conditions and/or whose insomnia is not treated with prescription or over-the-counter medications. ${ }^{6}$ Chronic insomnia is also associated with higher rates of workplace and non-work accidents. ${ }^{\text {? }}$

This review will introduce suvorexant, beginning with a summary of orexin system neurobiology and the development of orexin receptor antagonists. It will then touch on considerations that arose during the FDA's initial review of suvorexant and that affected the dosages approved, and then will focus on clinical considerations including prescribing guidelines and side effects, both observed and potential based on the drug's unique mechanism, that may occur with its use.

\section{Orexin system neurobiology and drug development}

The neurobiology of sleep and wakefulness is complex. Most existing medications for insomnia act, where the mechanism

Table I Mechanisms of medications used for sleep

\begin{tabular}{|c|c|c|}
\hline Medication(s) & Medication class & $\begin{array}{l}\text { Neurotransmitter system affected } \\
\text { for sleep effect }\end{array}$ \\
\hline Suvorexant & Dual orexin receptor antagonist & Orexin (hypocretin) \\
\hline $\begin{array}{l}\text { Prolonged-release melatonin }{ }^{58} \\
\text { Ramelteon } \\
\text { Tasimelteon }^{58}\end{array}$ & $\begin{array}{l}\text { MT agonist (melatonin is nonselective; } \\
\text { ramelteon and tasimelteon are selective } \\
\text { for } M T 1 \text { and } M T 2 \text { receptors) }\end{array}$ & Melatonin (may enhance GABA effect) \\
\hline $\begin{array}{l}\text { Zolpidem } \\
\text { Zaleplon } \\
\text { Zopiclone } \\
\text { Eszopiclone }\end{array}$ & $\begin{array}{l}\text { Benzodiazepine receptor agonist; } \mathrm{GABA}_{\mathrm{A}} \\
\text { receptor positive allosteric modulator }\end{array}$ & $\mathrm{GABA}_{\mathrm{A}}$ \\
\hline $\begin{array}{l}\text { Doxepin } \\
\text { Amitriptyline* }\end{array}$ & Tricyclic antidepressant & $\begin{array}{l}\text { Histamine (HI) (doxepin at low dose, } \\
3-6 \mathrm{mg} \text { ) } \\
\text { Histamine, serotonin, acetylcholine, } \\
\text { norepinephrine (class effect, including } \\
\text { doxepin at higher doses) }\end{array}$ \\
\hline $\begin{array}{l}\text { Diphenhydramine } \\
\text { Doxylamine }\end{array}$ & Antihistamines & Histamine $(\mathrm{HI})$ \\
\hline $\begin{array}{l}\text { Estazolam } \\
\text { Flunitrazepam } \\
\text { Flurazepam } \\
\text { Quazepam } \\
\text { Nitrazepam } \\
\text { Temazepam Triazolam }\end{array}$ & $\begin{array}{l}\text { Benzodiazepines; } \\
\text { GABA }_{A} \text { receptor positive allosteric } \\
\text { modulator }\end{array}$ & $\mathrm{GABA}_{\mathrm{A}}$ (nonspecific) \\
\hline $\begin{array}{l}\text { Butalbital Pentobarbital- } \\
\text { carbromal Secobarbital }\end{array}$ & $\begin{array}{l}\text { Barbiturates;" } \\
\text { GABA }_{A} \text { receptor positive allosteric modulator }\end{array}$ & GABA \\
\hline Trazodone* & Serotonin antagonist and reuptake inhibitor & Serotonin \\
\hline Quetiapine* & Atypical antipsychotic & Histamine $(\mathrm{HI})$ \\
\hline Mirtazapine* & $\begin{array}{l}\text { Noradrenergic and specific serotonergic } \\
\text { antidepressant }\end{array}$ & Serotonin and histamine ${ }^{59}$ \\
\hline
\end{tabular}

Notes: Not all medications listed are available in all countries. *Use for insomnia is off-label in all countries where the medication is approved. \# Use not advised. Data from Roehrs and Roth ${ }^{57}$ except as otherwise referenced.

Abbreviations: $\mathrm{GABA}_{\mathrm{A}}$, gamma-aminobutyric acid class $A ; M T$, melatonin. 
is understood, by promoting inhibitory neurotransmission at gamma-aminobutyric acid class $\mathrm{A}\left(\mathrm{GABA}_{\mathrm{A}}\right)$ receptors or by antagonizing histaminic neurotransmission, a pro-arousal system (Table 1). A medication that more specifically targets the wake-promoting system has the potential for fewer side effects and better efficacy, ${ }^{8}$ though the ideal sleep medication (Table 2) does not yet exist.

In early 1998, two research groups essentially simultaneously published descriptions from rat studies of a newly identified pair of neuropeptides originating in the neurons in the lateral and dorsal hypothalamus. ${ }^{9,10}$ One group called them "hypocretin" 1 and 2 and observed their excitatory effect on direct application to some hypothalamic neurons; $;$ the other group called them "orexin" A and B and noted their stimulant effect on appetite and their production in response to fasting. ${ }^{10}$ Both terms are still in use for these neuropeptides; this review will use "orexins". Orexin $\mathrm{A}$ and $\mathrm{B}$ are isoforms, 33- and 28-amino acids respectively, arising from the same precursor (prepro-orexin or preprohypocretin).

Based on the destinations of orexin-releasing axonal projections from the hypothalamus, orexins were soon hypothesized to play a role in the regulation of sleep and wake. ${ }^{11}$ Within 18 months, a mutation in the gene for one of two orexin receptors was reported to be the cause of canine narcolepsy, ${ }^{12}$ a condition identified in the 1970 s as an autosomal recessive genetic condition in some breeds. ${ }^{13}$ The subsequent finding that orexin was undetectable in the cerebrospinal fluid (CSF) of seven human patients with narcolepsy ${ }^{14}$ was published less than 6 months later and cemented the understanding that the orexin system is key in this disease and in sleep/wake regulation.

While many neurotransmitters play a role in arousal, the orexin system is crucial to maintaining wakefulness and suppressing both sleep and muscle atonia. ${ }^{15,16}$ Orexinproducing neurons are located solely in the hypothalamus, where they have a close anatomic relationship with melanin-concentrating hormone-producing neurons ${ }^{17}$ and, though relatively few in number, project axons widely through the brain. ${ }^{11}$ Orexin A and B are the neuropeptides; orexin receptor 1 and 2, also called hypocretin receptor types 1 and 2, are G protein-coupled receptors to which they bind.

With the identification of the orexin receptors, pharmaceutical development began. Several different chemical structures proved to bind one or both receptors, providing foundations on which to design molecules with pharmacologically important features. Suvorexant was developed by an iterative design-and-test process starting with a basic diazepane structure, with features added to improve penetration into the central nervous system (CNS), and further chemical alterations made to improve oral bioavailability, pharmacokinetics, biochemical stability, and ease of synthesis including enantioselectivity. ${ }^{18}$

Antagonists that bind a single orexin receptor are called SORAs, and dual orexin receptor antagonists are called DORAs. To date, at least four DORAs have undergone clinical trials: suvorexant (MK-4305; Merck), filorexant

Table 2 Characteristics of a hypothetical ideal sleep medication

\begin{tabular}{|c|c|c|}
\hline & Benefits provided & Adverse effects avoided \\
\hline \multirow[t]{11}{*}{ Subjective experience } & Improved, satisfactory sleep experience & No unusual experiences during sleep \\
\hline & Reduction in daytime fatigue & No unusual dreams \\
\hline & Rapid onset & No sleepwalking, etc \\
\hline & Duration extends over desired sleep time & No unusual/adverse experiences while awake \\
\hline & Rapid offset & No sleep paralysis \\
\hline & Effective with use on an as-needed basis & No dizziness \\
\hline & Effective without regard to food or alcohol intake & No unsteadiness or fall risk \\
\hline & & Minimal to no other side effects (dry mouth, etc) \\
\hline & & Low cost or copay \\
\hline & & No risk of overdose \\
\hline & & No risk of dependence, tolerance, withdrawal \\
\hline \multirow[t]{9}{*}{ Objective considerations } & Improved objective measures of sleep on & No respiratory depression \\
\hline & polysomnography & No other medical adverse effects (arrhythmia, priapism, etc) \\
\hline & Improved daytime functioning & No fall risk \\
\hline & Reduced health care costs & No interactions with other medications \\
\hline & & No street value \\
\hline & & No increased risk of accidents \\
\hline & & Low cost \\
\hline & & No risk of overdose \\
\hline & & No risk of dependence, tolerance, withdrawal \\
\hline
\end{tabular}


(MK-6906; Merck), SB-649,868 (GlaxoSmithKline), and almorexant (ACT-078573; Actelion, Allschwil, Switzerland). Almorexant was the first to show efficacy in Phase II trials $^{18}$ but development was stopped, possibly due to toxicity. Additional DORAs and SORAs are in active development. ${ }^{19,20}$

Orexins seem to play a central role in the regulation and integration of many physiologic systems: energy metabolism, appetite and feeding behavior, reward and addiction, anxiety and panic, nociception, migraine, olfaction, physical activity (locomotion), and stress responses including cardiovascular response. ${ }^{21}$ Research into these orexin-related functions and dysfunctions may lead to novel pharmaceuticals with therapeutic effects on problems such as addiction, anorexia, and obesity; however, suvorexant was not reported in Phase III trials ${ }^{22,23}$ to have side effects - beneficial or adverse - in these areas and thus potential orexin system effects outside of sleep and wake control lie outside the scope of this review.

\section{Clinical trials and approval}

Pharmaceutical company researchers studied suvorexant at doses up to $100 \mathrm{mg}$ in clinical trials and initially requested approval for suvorexant for sleep-onset and sleep-maintenance insomnia at doses of $20-40 \mathrm{mg}$ in adults up to age 65 and $15-35 \mathrm{mg}$ in adults age $\geq 65 .{ }^{24}$ At these doses, the drug was objectively effective at shortening time to sleep and lengthening sleep duration with a discontinuation rate that was not significantly different from placebo, with no higher risk of falls than placebo, and with no evidence of withdrawal or of drug abuse potential compared with placebo. ${ }^{22,23}$ However, the following adverse effects were also noted: excessive daytime sleepiness (reported two- to fourfold more by subjects on suvorexant than those on placebo), suicidal ideation (reported by $0.4 \%-0.8 \%$ of subjects on suvorexant compared with $0 \%-0.3 \%$ of those on placebo), and sleep paralysis, hypnopompic and hypnagogic hallucinations, and complex sleep-related behaviors (reported by $0.2 \%-0.6 \%$ of subjects on suvorexant compared with $0 \%$ of those on placebo). ${ }^{22,23}$

In May 2013, at a meeting of the FDA's Peripheral and Central Nervous System Drugs Advisory Committee, the FDA expressed concerns about safety at these doses. ${ }^{25}$ Zolpidem had undergone relabeling in January 2013 to advise lower doses for women based on the higher likelihood of therapeutic blood levels the next day, and to advise that patients be cautioned about the possibility of impaired function (particularly driving) even if they felt awake the next morning. ${ }^{3}$ Relabeling of other hypnotics was anticipated.
In the May 2013 committee meeting, the FDA expressed concern about "actual, not just ideal use" of sleep medications, the paucity of data on suvorexant use by people with multiple medical conditions and/or medications, observed side effects particularly at higher doses (including impaired next-day driving and suicidal ideation), and potential narcolepsy-like side effects. ${ }^{25}$ The FDA discussed its preference to "use the lowest dose effective for the patient". ${ }^{25}$ Based on trial data, the FDA observed: (a) that the objective benefits of suvorexant were similar at lower doses (10-20 mg) and higher doses (40 mg, for which approval was requested, and $80 \mathrm{mg}$ ); (b) that the lower doses appeared safer than the higher doses (particularly with regard to next-day driving and risk of suicidal ideation); and (c) that doses even lower than $10 \mathrm{mg}$ might prove to be effective and safe. ${ }^{25}$ The drug company, on the other hand, observed that the subjective benefit was not as great on 10-20 mg doses as on higher doses. $^{22-23}$ Suvorexant was approved in the United States in November 2014 at $20 \mathrm{mg}$ and lower doses. ${ }^{1}$

\section{Prescribing information}

Full United States prescribing information is available online $^{26}$ and is the source for this section except for pricing data. Suvorexant is indicated for the treatment of insomnia manifesting as difficulty achieving sleep and/or maintaining sleep and is approved for use without limitation on the duration of use. It is a controlled substance, Schedule-IV, as are the benzodiazepine receptor agonists including zolpidem.

Suvorexant should be taken within 30 minutes of bedtime and should not be taken with or shortly after a meal, as onset of action will be delayed. Its peak effect occurs around 2 hours on average, with a range of 30 minutes to 6 hours. It has a long elimination half-life of 12 hours and reaches steady state by the 3 rd day with regular use. It should only be taken when the patient will be able to stay in bed for at least 7 hours before arising and resuming activities, including driving.

Suvorexant comes in $5 \mathrm{mg}, 10 \mathrm{mg}, 15 \mathrm{mg}$, and $20 \mathrm{mg}$ tablets. The lowest dose that the patient finds effective should be used, with recommended initial dose for most adults of $10 \mathrm{mg}$, increasing to $20 \mathrm{mg}$ (the maximum recommended dose) if the lower dose is not effective after several nights but is well-tolerated. Important dosing considerations, interactions, and contraindications are listed in Table 3. Caution should be used in increasing the dose in obese women, as women and people with body mass index (BMI) $>30 \mathrm{~kg} / \mathrm{m}^{2}$ have higher peak levels and clear the drug more slowly than men and than people with BMI $\leq 25 \mathrm{~kg} / \mathrm{m}^{2}$. The peak 
Table 3 Important interactions and contraindications for suvorexant

\begin{tabular}{ll}
\hline Dosing consideration & Situation \\
\hline Dose adjustment not & Geriatric age \\
needed & Impaired renal function \\
Mild-to-moderate hepatic impairment & Obese female patients (consider reduced \\
Lower dose recommended & dose) \\
Moderate CYP3A inhibitors & Grapefruit juice \\
& Erythromycin, ciprofloxacin \\
& Diltiazem, verapamil \\
& Fluconazole \\
& Imatinib \\
Amprenavir, atazanavir, fosamprenavir & CNS depressants (reduce dose of one \\
& or both agents) \\
Narcolepsy \\
Severe hepatic impairment \\
Strong CYP3A inhibitors \\
Clarithromycin, telithromycin \\
Ketoconazole, itraconazole, \\
posaconazole \\
Nefazodone \\
Boceprevir, telaprevir \\
Indinavir, nelfinavir, ritonavir, saquinavir \\
CNS depressants (major) \\
Alcohol \\
Hypnotics \\
Opioids \\
Orphenadrine \\
Sodium oxybate \\
Thalidomide \\
\hline
\end{tabular}

Note: Data from Merck, Sharp, and Dohme. ${ }^{26}$

Abbreviation: CNS, central nervous system.

concentration is about $25 \%$ higher in obese women than in normal-weight women, and their total drug exposure (area under the curve) is about $46 \%$ higher. Suvorexant has not been studied in pregnancy or lactation in humans. In animal studies, the drug is excreted in breast milk, and very high maternal doses during pregnancy resulted in offspring with reduced body weight.

The Average Wholesale Price as of May 2015 was more than US\$10 per tablet for each of the four dose strengths. ${ }^{27}$

\section{Observed and potential adverse effects}

As expected for a hypnotic, suvorexant causes more sedation and fatigue than placebo. ${ }^{22,23} \mathrm{In}$ addition, even at the $10 \mathrm{mg}$ dose, twice as many research subjects reported abnormal dreams as did those taking placebo. ${ }^{24}$

Suicidal ideation was reported in Phase III trials, occurring in $0 \%-1.6 \%$ of subjects taking $10-20 \mathrm{mg}$ per night and in $3.4 \%-8.2 \%$ of subjects taking $40-80 \mathrm{mg}$ per night; ${ }^{24}$ those higher doses were not approved by the FDA and are not advised. Caution should be used in prescribing this medication to patients with depression.

The labeling refers to elevation in cholesterol levels, but at the approved doses this elevation was only $1-2 \mathrm{mg} / \mathrm{dL} .{ }^{26}$

Suvorexant is contraindicated in people with narcolepsy; ${ }^{26}$ that condition is rare at a prevalence of $<0.1 \%$, but is often associated with insomnia or disrupted sleep. ${ }^{28,29}$ Suvorexant has not been studied in people with narcolepsy, and it might have no therapeutic effect (given that orexin levels are already very low) and/or might exacerbate symptoms of narcolepsy (by blocking the effect of any orexin present at low levels). In a mouse model of narcolepsy, almorexant worsened cataplexy. ${ }^{30}$ Given its mechanism, suvorexant could be anticipated to cause, at least in some patients on some occasions, narcolepsy-like side effects unique to it among currently available hypnotics. Indeed sleep paralysis, hypnagogic/hypnopompic hallucinations, and possibly cataplexy were experienced by a few patients in Phase III studies, and the FDA raised concerns about one reported episode of unusual activity during a nocturnal polysomnogram suggestive of rapid eye movement (REM) sleep behavior disorder (RBD). ${ }^{25}$ In narcolepsy, the interface between REM state and wake state is blurred; suvorexant may cause some of the same effects. People with narcolepsy:

- transition from wake state directly into to REM state (experiencing hypnagogic hallucinations and on somnography exhibiting characteristic "sleep onset REM periods" or SOREMPs);

- transition while awake from normal muscle tone to REMlike atonia (cataplexy);

- transition from REM sleep to wake (experiencing hypnopompic hallucinations, and sleep paralysis if atonic);

- commonly exhibit REM sleep without atonia ${ }^{29}$ (RSWA) and RBD. ${ }^{16,29,31}$

Prader-Willi syndrome appears to involve hypothalamic dysfunction and can be associated with narcolepsy-like sleepwake patterns ${ }^{32,33}$ and with narcolepsy, ${ }^{34}$ making it another condition in which suvorexant probably should not be used.

Some people without narcolepsy manifest some of the same blurring of REM and wake (Table 4), whether or not they are aware of it. There is no mention in the prescribing information for suvorexant regarding its use in these conditions, including antidepressant use, isolated sleep paralysis (ISP), isolated cataplexy, and RBD.

RSWA is observed in people without narcolepsy who have depression and who take antidepressants, ${ }^{35,36}$ particularly serotonergic antidepressants, ${ }^{35}$ and RBD is not only well-associated with neurodegenerative diseases such as 
Table 4 Normal and abnormal combinations of REM/wake brain state and muscle tone

\begin{tabular}{|c|c|c|}
\hline & \multicolumn{2}{|l|}{ Muscle state } \\
\hline & $\begin{array}{l}\text { Tone normal (or not } \\
\text { reduced) }\end{array}$ & Hypotonia/atonia \\
\hline \multicolumn{3}{|l|}{ Brain state } \\
\hline Awake & Normal wake state & $\begin{array}{l}\text { Cataplexy } \\
\text { Sleep paralysis }\end{array}$ \\
\hline REM sleep & $\begin{array}{l}\text { RSWA } \\
\text { RBD }\end{array}$ & Normal REM sleep \\
\hline
\end{tabular}

Note: Non-REM (NREM) sleep not shown.

Abbreviations: REM, rapid eye movement; RBD, REM sleep behavior disorder; RSWA, REM sleep without atonia.

Parkinson's but is also observed in association with depression and with use of selective serotonin reuptake inhibitors. ${ }^{37}$ RBD can cause injury to the patient or bed partner.

ISP is more common than narcolepsy, with almost $8 \%$ of the general population, $28 \%$ of college students, and $35 \%$ of people with panic disorder diagnoses reporting experiencing it at least once. ${ }^{38}$ ISP is more prevalent in African Americans, with almost $40 \%$ of blacks without psychiatric conditions reporting experiencing an ISP experience at least once (ever), $14 \%$ at least once a year, and more than $5 \%$ at least once a month, and with more than $5 \%$ of blacks seeking mental health care experiencing ISP at least once a week. ${ }^{39}$ Sleep paralysis is not dangerous and is limited in duration but can be very frightening. Given the reported prevalence of ISP in the general population and particularly in blacks and in people with panic disorders, it would be prudent to warn all patients about the possibility of experiencing sleep paralysis while taking suvorexant.

Cataplexy, a sudden loss of muscle tone during wakefulness usually triggered by emotion, is a cardinal symptom of narcolepsy rarely observed in the absence of narcolepsy. However, there are case reports of cataplexy occurring in isolation, with ${ }^{40-42}$ and without ${ }^{43}$ an identified brain injury. In trials of suvorexant, reports of falls were adjudicated by an independent group for evidence of cataplexy. ${ }^{22,23}$ The fall rate was identical on placebo and suvorexant and no cataplexy-like events were identified on adjudication, ${ }^{22,23}$ though the FDA expressed concern about possible mild cataplexy events. ${ }^{25}$ When suvorexant is in more widespread use, including in people with certain brain injuries, cataplexy-like events may be experienced by a small number of patients. Cataplexy can result in injury.

Suvorexant increases both non-REM (NREM) and REM sleep, affecting REM more prominently, reducing latency to REM sleep and increasing the duration of REM sleep in animal studies ${ }^{44,45}$ Conditions that occur or worsen during REM sleep, $\mathrm{RBD}$, and (in some cases) obstructive sleep apnea (OSA), might become more problematic on suvorexant.

RBD is classically associated with neurodegenerative conditions, particularly the synucleinopathies (Parkinson's, Lewy body dementia, and multiple system atrophy), in which case it predominantly occurs in older men and can precede the diagnosis of the neurodegenerative condition by years or even decades. ${ }^{46} \mathrm{RBD}$ is also reported in $24 \%{ }^{29}-36 \%{ }^{47}$ (or more) of people with narcolepsy, in which case it is associated with orexin deficiency ${ }^{16}$ and affects males and females equally. ${ }^{29,47}$ RBD in either population might potentially worsen on suvorexant, since it promotes REM sleep and potentially due to its antagonistic effect at orexin receptors.

Suvorexant has not been studied in OSA, but at doses up to $40 \mathrm{mg}$ it did not worsen oxygenation or the apnea-hypopnea index in patients without OSA who had mild-to-moderate COPD. ${ }^{48}$ About half of people with OSA have worsened apneas and/or more impaired oxygenation during REM sleep. ${ }^{49,50}$ For such people, particularly those whose OSA is undiagnosed and/or untreated, a REM-enhancing sleep medication could potentially worsen sleep-disordered breathing. While OSA is common in narcolepsy, ${ }^{51}$ orexin deficiency does not seem to affect respiratory drive in humans, ${ }^{52}$ unlike in mice.$^{53}$

\section{Conclusion}

Suvorexant is the first of a new pharmaceutical class on the market, still to be tried and proven in use in a broad population outside of research studies. This review has introduced this new medication and class, including background to the drug's development, prescribing guidelines, and observed and potential side effects based on its unique mechanism. Suvorexant has a long half-life of 12 hours on average. It should be taken without food to avoid delaying its peak effect, and dosing should be conservative in women with BMI $>30 \mathrm{~kg} / \mathrm{m}^{2}$ because of higher peak levels and slower clearance. However, unlike most other hypnotic medications, dose adjustment is not needed for advanced age, renal impairment, or mild-to-moderate hepatic impairment. Suvorexant should not be used in combination with strong CYP3A inhibitors and is contraindicated in narcolepsy. As discussed in this review, suvorexant could exacerbate preexisting abnormalities of sleep-wake regulation, including in Prader-Willi syndrome, RBD, or ISP. Abnormal dreams, sleep paralysis, and suicidal ideation occurred in subjects taking suvorexant in studies but were reported to be mild and dose-related. Post-release, some patients taking this medication might experience cataplexy or RBD, based on its mechanism of action. 
SORAs and other DORAs will very likely follow suvorexant to the market in years to come, for treatment of sleep-wake disorders and for other orexin-related therapeutic effects. Current and future research into the neurobiology $y^{54,55}$ and neuropharmacology ${ }^{56}$ of insomnia may eventually lead to the improved identification of specific types of insomnia and specific patient populations for which tailored treatment approaches using novel pharmaceuticals could prove to be particularly effective. ${ }^{57}$

\section{Disclosure}

The author reports no conflicts of interest in this work.

\section{References}

1. United States Food and Drug Administration. FDA News Release: FDA Approves New Type of Sleep Drug. Belsomra; 2014. Available from: http://www.fda.gov/NewsEvents/Newsroom/PressAnnouncements/ ucm409950.htm. Accessed March 17, 2015.

2. Parker T. Merck enters the Insomnia market through the launch of Belsomra in Japan. GlobalData Website; 2014. Available from: http:// healthcare.globaldata.com/resources/expert-insights/pharmaceuticals/ merck-enters-the-insomnia-market-through-the-launch-of-belsomra-injapan. Accessed May 12, 2015.

3. United States Food and Drug Administration. FDA drug safety communication: risk of next-morning impairment after use of insomnia drugs; FDA requires lower recommended doses for certain drugs containing zolpidem (Ambien, Ambien CR, Edluar, and Zolpimist); 2013. Available from: http://www.fda.gov/downloads/Drugs/DrugSafety/ UCM335007.pdf. Accessed March 17, 2015.

4. American Academy of Sleep Medicine. International Classification of Sleep Disorders. 3rd ed. Darien, IL: American Academy of Sleep Medicine; 2014.

5. The National Sleep Foundation. 2014 Sleep Health Index 2014. Available from: http://sleepfoundation.org/sleep-health-index

6. Sarsour K, Kalsekar A, Swindle R, Foley K, Walsh JK. The association between insomnia severity and healthcare and productivity costs in a health plan sample. Sleep. 2011;34(4):443-450.

7. Kessler RC, Berglund PA, Coulouvrat C, et al. Insomnia, comorbidity, and risk of injury among insured Americans: results from the America Insomnia Survey. Sleep. 2012;35(6):825-834.

8. Winrow CJ, Renger JJ. Discovery and development of orexin receptor antagonists as therapeutics for insomnia. Br J Pharmacol. 2014; 171(2):283-293.

9. de Lecea L, Kilduff TS, Peyron C, et al. The hypocretins: hypothalamusspecific peptides with neuroexcitatory activity. Proc Natl Acad Sci US A. 1998;95(1):322-327.

10. Sakurai T, Amemiya A, Ishii M, et al. Orexins and orexin receptors: a family of hypothalamic neuropeptides and $\mathrm{G}$ protein-coupled receptors that regulate feeding behavior. Cell. 1998;92:573-585.

11. Peyron C, Tighe DK, van den Pol AN, et al. Neurons containing hypocretin (orexin) project to multiple neuronal systems. J Neurosci. 1998;18(23):9996-10015.

12. Lin L, Faraco J, Li R, et al. The sleep disorder canine narcolepsy is caused by a mutation in the hypocretin (orexin) receptor 2 gene. Cell. 1999;98(3):365-376.

13. Foutz AS, Mitler MM, Cavalli-Sforza LL, Dement WC. Genetic factors in canine narcolepsy. Sleep. 1979;1(4):413-421.

14. Nishino S, RipleyB, Overeem S, Lammers GJ, Mignot E. Hypocretin(orexin) deficiency in human narcolepsy. Lancet. 2000;355(9197):39-40.

15. Lee MG, Hassani OK, Jones BE. Discharge of identified orexin/ hypocretin neurons across the sleep-waking cycle. J Neurosci. 2005; 25:6716-6720.
16. Knudsen S, Gameltoft S, Jennum PJ. Rapid eye movement sleep behaviour disorder in patients with narcolepsy is associated with hypocretin-1 deficiency. Brain. 2010;133(pt 2):568-579.

17. Broberger C, De Lecea L, Sutcliffe JG, Hökfelt T. Hypocretin/orexinand melanin-concentrating hormone-expressing cells form distinct populations in the rodent lateral hypothalamus: relationship to the neuropeptide Y and agouti gene-related protein systems. J Comp Neurol. 1998; 402(4):460-474.

18. Cox CD, Breslin MJ, Whitman DB, et al. Discovery of the dual orexin receptor antagonist [(7R)-4-(5-chloro-1,3-benzoxazol-2-yl)7-methyl-1,4-diazepan-1-yl] [5-methyl-2-(2H-1,2,3-triazol-2-yl)phenyl] methanone (MK-4305) for the treatment of insomnia. J Med Chem. 2010; 53(14):5320-5332.

19. Raheem IT, Breslin MJ, Bruno J, et al. Discovery of piperidine ethers as selective orexin receptor antagonists (SORAs) inspired by filorexant. Bioorg Med Chem Lett. 2015;25(3):444-450.

20. Roecker AJ, Mercer SP, Bergman JM, et al. Discovery of diazepane amide DORAs and 2-SORAs enabled by exploration of isosteric quinazoline replacements. Bioorg Med Chem Lett. 2015. [Epub ahead of print]

21. Li J, Hu Z, de Lecea L. The hypocretins/orexins: integrators of multiple physiological functions. Br J Pharmacol. 2014;171(2): 332-350.

22. Herring WJ, Connor KM, Ivgy-May N, et al. Suvorexant in patients with insomnia: results from two 3-month randomized controlled clinical trials. Biol Psychiatry. 2014. [Epub ahead of print]

23. Michelson D, Snyder E, Paradis E, et al. Safety and efficacy of suvorexant during 1-year treatment of insomnia with subsequent abrupt treatment discontinuation: a phase 3 randomised, double-blind, placebocontrolled trial. Lancet Neurol. 2014;13(5):461-471.

24. Margaretten N, Herring WJ, Michelson D; for Merck, Sharp, \& Dohme Corporation. Merck Sharp and Dohme Presentations for the May 22, 2013 Meeting of the Peripheral and Central Nervous System Drugs Advisory Committee. Available from: http://www.fda.gov/ downloads/AdvisoryCommittees/CommitteesMeetingMaterials/ Drugs/PeripheralandCentralNervousSystemDrugsAdvisoryCommittee/ UCM354216.pdf. At U.S. FDA, Slides for the May 22, 2013 Meeting of the Peripheral and Central Nervous System Drugs Advisory Committee. 2013 Meeting Materials, Peripheral and Central Nervous System Drugs Advisory Committee. Available from: http://www. fda.gov/AdvisoryCommittees/CommitteesMeetingMaterials/Drugs/ PeripheralandCentralNervousSystemDrugsAdvisoryCommittee/ ucm354213.htm. Accessed March 17, 2015.

25. Farkins R, for U.S. FDA. FDA Presentations for the May 22, 2013 Meeting of the Peripheral and Central Nervous System Drugs Advisory Committee. Available from: http://www.fda.gov/downloads/ AdvisoryCommittees/CommitteesMeetingMateDrugs/PeripheralandCentralNervousSystemDrugsAdvisoryCommittee/UCM354215.pdf. At U.S. FDA, Slides for the May 22, 2013 Meeting of the Peripheral and Central Nervous System Drugs Advisory Committee. Available from: http://www.fda.gov/AdvisoryCommittees/CommitteesMeetingMaterials/Drugs/PeripheralandCentralNervousSystemDrugsAdvisoryCommittee/ucm354213.htm. Accessed March 17, 2015.

26. Merck, Sharp, \& Dohme. Belsomra (Suvorexant): Full Prescribing Information; 2014. Available from: https://www.merck.com/product/ usa/pi_circulars/b/belsomra/belsomra_pi.pdf. Accessed March 17, 2015.

27. Lexicomp Online. Suvorexant: Drug Information. Hudson, OH: LexiComp, Inc; 2014.

28. Roth T, Dauvilliers Y, Mignot E, et al. Disrupted nighttime sleep in narcolepsy. J Clin Sleep Med. 2013;9(9):955-965.

29. Frauscher B, Ehrmann L, Mitterling T, et al. Delayed diagnosis, range of severity, and multiple sleep comorbidities: a clinical and polysomnographic analysis of 100 patients of the Innsbruck narcolepsy cohort. J Clin Sleep Med. 2013;9(8):805-812.

30. Black SW, Morairty SR, Fisher SP, Chen TM, Warrier DR, Kilduff TS. Almorexant promotes sleep and exacerbates cataplexy in a murine model of narcolepsy. Sleep. 2013;36(3):325-336. 
31. Nevsimalova S, Prihodova I, Kemlink D, Lin L, Mignot E. REM behavior disorder (RBD) can be one of the first symptoms of childhood narcolepsy. Sleep Med. 2007;8:784-786.

32. Bruni O, Verrillo E, Novelli L, Ferri R. Prader-Willi syndrome: sorting out the relationships between obesity, hypersomnia, and sleep apnea. Curr Opin Pulm Med. 2010;16(6):568-573.

33. Blecher G, Wainbergas N, McGlynn M, Teng A. Rapidly evolving narcolepsy-like syndrome coinciding with severe OSA following pharyngoplasty in Prader-Willi syndrome. Respirol Case Rep. 2014; 2(3):111-112.

34. Sedky K, Bennett DS, Pumariega A. Prader Willi syndrome and obstructive sleep apnea: co-occurrence in the pediatric population. J Clin Sleep Med. 2014;10(4):403-409.

35. Winkelman JW, James L. Serotonergic antidepressants are associated with REM sleep without atonia. Sleep. 2004;27(2):317-321.

36. McCarter SJ, St Louis EK, Sandness DJ, et al. Antidepressants increase REM sleep muscle tone in patients with and without REM sleep behavior disorder. Sleep. 2015;38(6):907-917.

37. Frauscher B, Jennum P, Ju YE, et al. Comorbidity and medication in REM sleep behavior disorder: a multicenter case-control study. Neurology. 2014;82(12):1076-1079.

38. Sharpless BA, Barber JP. Lifetime prevalence rates of sleep paralysis: a systematic review. Sleep Med Rev. 2011;15(5):311-315.

39. Bell CC, Shakoor B, Thompson B, et al. Prevalence of isolated sleep paralysis in black subjects. J Natl Med Assoc. 1984;76(5):501-508.

40. Mignot E, Lammers GJ, Ripley B, et al. The role of cerebrospinal fluid hypocretin measurement in the diagnosis of narcolepsy and other hypersomnias. Arch Neurol. 2002;59(10):1553-1562.

41. D'Cruz OF, Vaughn BV, Gold SH, Greenwood RS. Symptomatic cataplexy in pontomedullary lesions. Neurology. 1994;44(11):2189-2191. [Erratum in: Neurology 1995;45(11):2123].

42. Reynolds TQ, Roy A. Isolated cataplexy and REM sleep behavior disorder after pontine stroke. J Clin Sleep Med. 2011;7(2):211-213.

43. van Dijk JG, Lammers GJ, Blansjaar BA. Isolated cataplexy of more than 40 years' duration. Br J Psychiatry. 1991;159:719-721.

44. Etori K, Saito YC, Tsujino N, Sakurai T. Effects of a newly developed potent orexin-2 receptor-selective antagonist, compound $1 \mathrm{~m}$, on sleep/ wakefulness states in mice. Front Neurosci. 2014;8:8.

45. Betschart C, Hintermann S, Behnke D, et al. Identification of a novel series of orexin receptor antagonists with a distinct effect on sleep architecture for the treatment of insomnia. J Med Chem. 2013; 56(19):7590-7607.
46. Boeve BF, Silber MH, Ferman TJ, et al. Clinicopathologic correlations in 172 cases of rapid eye movement sleep behavior disorder with or without a coexisting neurologic disorder. Sleep Med. 2013;14(8):754-762.

47. Nightingale S, Orgill JC, Ebrahim IO, de Lacy SF, Agrawal S, Williams AJ. The association between narcolepsy and REM behavior disorder (RBD). Sleep Med. 2005;6(3):253-258.

48. Sun H, Palcza J, Rosenberg R, et al. Effects of suvorexant, an orexin receptor antagonist, on breathing during sleep in patients with chronic obstructive pulmonary disease. Respir Med. 2015;109(3):416-426.

49. Muraki M, Kitaguchi S, Ichihashi H, et al. Apnoea-hypopnoea index during rapid eye movement and non-rapid eye movement sleep in obstructive sleep apnoea. J Int Med Res. 2008;36(5):906-913.

50. Loadsman JA, Wilcox I. Is obstructive sleep apnoea a rapid eye movementpredominant phenomenon? Br J Anaesth. 2000;85(3):354-358.

51. Jennum P, Ibsen R, Knudsen S, Kjellberg J. Comorbidity and mortality of narcolepsy: a controlled retro- and prospective national study. Sleep. 2013;36(6):835-840.

52. Han F. Respiratory regulation in narcolepsy. Sleep Breath. 2012;16(1): 241-245.

53. Terada J, Nakamura A, Zhang W, et al. Ventilatory long-term facilitation in mice can be observed during both sleep and wake periods and depends on orexin. J Appl Physiol (1985). 2008;104(2):499-507.

54. Gill JM, Lee H, Baxter T, et al. A diagnosis of insomnia is associated with differential expression of sleep-regulating genes in military personnel. Biol Res Nurs. 2015;17(4):384-392.

55. Prober DA, Rihel J, Onah AA, Sung RJ, Schier AF. Hypocretin/orexin overexpression induces an insomnia-like phenotype in zebrafish. J Neurosci. 2006;26(51):13400-13410.

56. Zisapel N. Current phase II investigational therapies for insomnia. Expert Opin Investig Drugs. 2015;24(3):401-411.

57. Roehrs T, Roth T. Insomnia pharmacotherapy. Neurotherapeutics. 2012; 9(4):728-738.

58. Hardeland R. New approaches in the management of insomnia: weighing the advantages of prolonged-release melatonin and synthetic melatoninergic agonists. Neuropsychiatr Dis Treat. 2009;5: 341-354

59. Dolder CR, Nelson MH, Iler CA. The effects of mirtazapine on sleep in patients with major depressive disorder. Ann Clin Psychiatry. 2012; 24(3):215-224
Drug Design, Development and Therapy

\section{Publish your work in this journal}

Drug Design, Development and Therapy is an international, peerreviewed open-access journal that spans the spectrum of drug design and development through to clinical applications. Clinical outcomes, patient safety, and programs for the development and effective, safe, and sustained use of medicines are a feature of the journal, which

\section{Dovepress}

has also been accepted for indexing on PubMed Central. The manuscript management system is completely online and includes a very quick and fair peer-review system, which is all easy to use. Visit http://www.dovepress.com/testimonials.php to read real quotes from published authors. 